\title{
KUINKA BONGAAT KULTAISEN, VIHREÄN TAI HYBRIDIKANAVAN? AVOIMEN SAATAVUUDEN TIEDOT JULKAISUFOORUMISSA
}

\author{
Tutkimusjulkaisujen välittömään avoimuuteen liittyvien \\ vaatimusten vuoksi tarvitaan työkaluja julkaisukanavien \\ avoimuuden tunnistamiseen. Julkaisufoorumin ylläpitämä \\ JUFO-portaali tarjoaa monenlaisia tietoja avoimuudesta ja \\ tietopohjaa on tarkoitus kehittää edelleen.
}

\section{A} voimeen julkaisemiseen liittyvä keskustelu on käynyt kuumana tiede- ja tutkimusyhteisössä jo hyvän aikaa. Tiede- ja tutkimusrahoittajien yhteisö coslition $s$ vaatii, että vuoden 202 I alusta lähtien koalition rahoittaman tutkimuksen tuotokset tulee julkaista välittömästi avoimina. Tutkimusjulkaisujen välittömän avoimuuden vaatimus koskee vuodesta 202 I lähtien siten muun muassa Suomen Akatemian rahoittamaa tutkimusta.

Suomessa on lisäksi tehty tutkimusjulkaisujen avointa saatavuutta koskeva kansallinen linjaus (Tutkimusjulkaisujen avoin saatavuus - tutkimusyhteisön kansallinen linjaus ja toimenpideohjelma 2020-2025, 2019), jonka yhtenä tavoitteena on se, että viimeistään vuonna 2022 kaikki uudet tieteelliset artikkeli- ja konferenssijulkaisut ovat välittömästi avoimesti saatavilla. Muita julkaisutyyppejä koskevat osalinjaukset valmistuvat myöhemmin. Suuntaus on siis vahvasti kohti yhä kattavampaa tutkimusjulkaisujen välitöntä avointa saatavuutta sekä kansallisella että kansainvälisellä tasolla.
Mistä tietoa avoimuudesta? coAlition s:n vaatimusten eli Plan S -suunnitelman mukaiset kolme sallittua avoimen julkaisemisen tietä ovat (I) avoin julkaisukanava tai -alusta (gold OA), (2) julkaisuarkisto (rinnakkaistallennus eli green $\mathrm{OA}$ ) ja (3) siirtymäkausisopimukseen sitoutunut hybridilehti (Ala-Kyyny 2019). Tiede- ja tutkimusyhteisö raapii siis nyt aiheestakin päätään ja pohtii, kuinka tunnistaa näiden vaatimusten mukaiset julkaisukanavat.

COAlition s on käynnistänyt projektin, jonka tavoitteena on rakentaa Plan S Journal Checker eli työkalu, jonka avulla voisi helposti tarkistaa sen, mitkä julkaisukanavat ovat Plan S:n mukaisia. Työkalun odotetaan olevan toiminnassa marraskuussa 2020 (coAlition $S$ 2020). Julkaisukanavien avoimuutta koskevia tietoja on kuitenkin saatavilla jo nyt esimerkiksi Tieteellisten seurain valtuuskunnan (TSv) yhteydessä toimivan Julkaisufoorumin JUFO-portaalissa (http://jfp.csc.fi:808o/).

Portaali sisältää useista eri lähteistä koottua tietoa julkaisukanavien avoi- 


\begin{tabular}{|c|c|c|c|c|c|c|c|c|}
\hline JUFOID & TASO $^{-}$ & NIMI & $S / R$ & OA & wos & SCO & ERIH+ & VOL \\
\hline 84682 & 0 & European stroke jol & 0 & $\sigma$ & $\checkmark$ & & & $2 b$ \\
\hline 84736 & 0 & Sleep Science & 0 & $a$ & $\checkmark$ & $\checkmark$ & & 50 \\
\hline 84737 & 0 & Open journal of rac & 0 & $\partial$ & \multirow{2}{*}{\multicolumn{2}{|c|}{$\begin{array}{l}\text { DOAJ } \\
\text { Bielefeld Gold OA } \\
\text { Virta Gold } \\
\text { Virta Green }\end{array}$}} & & 100 \\
\hline 84739 & 0 & NPG & & 8 & & & & 75 \\
\hline 84745 & 0 & Frontiers in pediatr & 0 & a & $\checkmark$ & & & 150 \\
\hline
\end{tabular}

Kuva 1. Leijuke kertoo, mille listoille OA-kanava kuuluu.

muudesta. Tietokantaan integroidut avoimuutta koskevat tiedonlähteet ovat Directory of Open Access Journals (DOAJ), suomalaisia tiedelehtiä sisältävä Journal.fi, saksalaisen Bielefeldin yliopiston tuottama Bielefeld Gold OA -lista sekä VIRTA-julkaisutietopalvelu. Korkeakoulujen tutkimusjulkaisuja sisältävästä vıRTA-julkaisutietopalvelusta saadut tiedot ovat näistä tulkinnanvaraisimpia ja saattavat sisältää enemmän virheitä kuin kuratoidut listat.

Portaalin hakusivun OA-sarakkeessa julkaisukanavan kohdalla oleva lukkokuvake viittaa siihen, että kanava esiintyy jollakin avoimuutta kuvaavalla listalla. Kuvakkeen yhteydessä oleva leijuke kertoo puolestaan tarkemmin, mille kaikille listoille kanava kuuluu (kuva I). Hakua voi myös rajata mainittujen tiedonlähteiden mukaan, esimerkiksi jos haluaa tarkastella mitkä julkaisukanavista on indeksoitu DOAJ:ssa.

Visuaalinen esitystapa on aiheuttanut jonkin verran hämmennystä ja toiveita siitä, ettei kaikkia avoimuuden tyyppejä niputettaisi näkymässä yhteen, vaan esimerkiksi hybridikanavat erotettaisiin näkymässä selkeästi muista julkaisukanavista. Tämän erottelun voi jo nyt tehdä käyttämällä hakutoimintoja, joskin hybridikanavista on tietokannassa toistaiseksi saatavilla rajallisesti tietoja.
Kultaiset eli välittömästi avoimet julkaisukanavat JUFO-portaalissa

JUFO-portaalin välitöntä avoimuutta koskevina tiedonlähteinä toimivat DOAJ ja Bielefeld Gold OA -lista, Journal.fi ja VIRTA. DOAJ-tiedot päivittyvät kuukausittain, Bielefeldin listaa ja Journal.fi-tietoja puolestaan päivitetään vain vuosittain, koska päivitystyö on manuaalista. VIRTA-tiedot päivittyvät viikoittain. Välitöntä avoimuutta koskevia tiedonlähteitä on käytössä eniten, koska niitä on ollut parhaiten saatavilla - ja ennen kaikkea avoimesti.

DOAJ sisältää noin I4 000 avointa julkaisukanavaa eli vain osan maailmassa julkaistuista avoimista julkaisukanavista. Esimerkiksi Pohjoismaissa julkaistavista avoimista lehdistä 42 prosenttia on indeksoitu DOAJ:ssa, ja suomalaisista avoimista lehdistä arviolta vain 23 prosenttia (Björk 2019). Suomessa DOAJ-kattavuutta pyritään parantamaan TSV:n ja DOAJ:n yhteisessä Suomalaiset tiedelehdet DOAJ-rekisteriin -projektissa (Julkaisufoorumi 2019).

Bielefeldin listan vuonna 2019 julkaistu versio 3.0 sisältää noin 37800 lehteä, joten se laajentaa JuFo-portaalin avoimuutta koskevaa tietopohjaa merkittävästi. Listan tiedonlähteinä toimivat DOAj:n ohella PubMed Central 
(PMC), Open APC (OAPC) ja Directory of Open Access Scholarly Resources (ROAD) (Bruns et al. 20I9).

JUfO-portaalin välittömän avoimuuden tiedonlähteistä tulkinnanvaraisempi tapaus on Journal.fi. Valtaosa palvelun lehdistä on välittömästi avoimia, mutta osalla on myös käytössään julkaisuviive eli embargo. Journal.fi:n embargolliset lehdet olisi toistaiseksi mahdollista erotella välittömästi avoimista ainoastaan yksittäisten lehtien verkkosivuja tutkimalla, mihin tällä hetkellä ei ole resursseja. Virta Gold -tiedot toimivat lähinnä suuntaa-antavina tietoina mahdollisten kirjausvirheiden vuoksi.

DOAj:n ja Bielefeldin listan yhdistelmän ansiosta välittömästi avoimia kanavia koskeva tietopohja on kuitenkin jo melko vankka.

\section{Rinnakkaistallennusta ja hybridikanavia koskevat tiedot JUFO-portaalissa}

JUFO-portaalin rinnakkaistallennusta koskeva tietopohja on välittömästi avoimia kanavia keveämpi - ja hybridejä koskeva tieto on toistaiseksi vielä tätäkin vähäisempää. Hybridijulkaisukanaviin liittyvä tieto perustuu portaalissa tällä hetkellä ainoastaan
VIRTA-julkaisutietopalvelun tietoihin.

Julkaisukanavien rinnakkaistallennuspolitiikasta kertovat JUFO-portaalissa Sherpa/RoMEO-tietokannasta saatavat tiedot. Sherpa/RoMEO on Nottinghamin yliopiston kehittämä palvelu, joka kuvaa julkaisun kustantajan tai lehden rinnakkaistallennuspolitiikkaa värikoodien avulla. Taulukossa I. kuvataan, mitä käsikirjoitusversioita tietyllä värikoodilla varustettu julkaisukanava sallii rinnakkaistallennettavan.

Sherpa/RoMEO-värikoodien ongelmana on se, että kaikkiin värikoodeihin kuuluvilla lehdillä voi rinnakkaistallennusehtojen lisäksi olla embargoaikoja tai muita erityisrajoitteita. Näin ollen Sherpa/RoMEOn tietojen perusteella ei tällä hetkellä pysty suoraan tekemään päätelmiä siitä, mitkä julkaisukanavat ovat Plan S -yhteensopivia. Myöskään viRTA-julkaisutietopalvelun rinnakkaistallennusta koskevista tiedoista ei ole lisäapua rinnakkaistallennettavien kanavien luotettavassa tunnistamisessa.

Sherpa/RoMEOn arkkitehtuuria ollaan kuitenkin kehittämässä Plan S:n vaatimusten mukaisesti. Värikoodien tilalle on tulossa tieto siitä, millä ehdoilla mikäkin versio käsikirjoituksesta voidaan julkais-

\begin{tabular}{c|c|c|c|c} 
& Vihreä & Sininen & Keltainen & Valkoinen \\
\hline $\begin{array}{c}\text { Vertaisarvioimaton } \\
\text { käsikirioitusversio }\end{array}$ & $\checkmark$ & & $\checkmark$ & \\
\hline $\begin{array}{c}\text { Arvioitu lopullinen } \\
\text { artikkeliversio }\end{array}$ & $\checkmark$ & $\checkmark$ & & \\
\hline $\begin{array}{c}\text { Kustantajan } \\
\text { PDF-versio }\end{array}$ & $\checkmark$ & $\checkmark$ & & \\
\hline
\end{tabular}

Taulukko 1. Sherpa/RoMEOn värikoodit ja käsikirjoitusversio(t), joiden rinnakkaistallentaminen on sallittua. 
ta avoimesti. Sherpa/RoMEOn uusi kehitysversio löytyy osoitteesta http://v2.sherpa.ac.uk/romeo.

\section{Haussa lisää lähteitä}

JUFO-portaali sisältää siis tällä hetkellä melko kattavasti tietoja välittömästi avoimista julkaisukanavista, jonkin verran tietoa rinnakkaistallennuksesta ja hyvin rajallisesti tietoa hybridijulkaisukanavista. Plan S -yhteensopivien julkaisukanavien tunnistamiseen tämänhetkiset tiedot eivät yksin riitä, mutta tietopohjaa on tarkoitus kehittää edelleen. Kaikkiaan tavoitteena on tukea tutkimusjulkaisujen avointa saatavuutta tarjoamalla tiede- ja tutkimusyhteisölle käyttökelpoinen tiedonlähde, joka kuvaa kattavasti ja monipuolisesti julkaisukanavien avoimuutta.
Julkaisufoorumi seuraa Plan S:n Journal Checkerin kehitystä ja selvittää myös muiden julkaisukanavien avoimuutta kuvaavien tiedonlähteiden integrointimahdollisuuksia. Tiedonlähteitä, joiden kautta voitaisiin saada kattavampaa tietoa esimerkiksi rinnak-

voisivat olla esimerkiksi JournalTocs tai Unpaywall. Alustavia keskusteluja on käyty tutkimusta koskevaa linkitettyä tietoa kokoavan Dimensionsin kanssa, jonka avoimuutta koskeva data on peräisin Unpaywallista. Tulevaisuudessa JUFO-portaaliin toivotaan saatavan tietoa myös esimerkiksi siitä, millaisia APC-maksuja ja niihin liittyviä sopimuksia tutkimusorganisaatioilla on.

\section{Julkaistut lähteet:}

Ala-Kyyny, J. (2019). Plan S astuu voimaan 202 I - avoimen julkaisemisen suunnitelma valmistui. Think Open I0.6.20 I9. https://blogs.helsinki.fi/ thinkopen/plan-s-toukokuu-2019/

BJÖRK, B.-C. (20I9). Open access journal publishing in the Nordic countries. Learned Publishing Volume 32, Issue 3 , Pages 227-236. https://doi.org/IO.I002/ leap.I23 I

Bruns, A.; Lenke, C.; Schmidt, C. \& Taubert, N. (2019). IsSN-Matching of Gold OA Journals (ISSN-GOLD-OA). Additional Information for Version 3.o. April Ioth, 2019. https://pub.uni-bielefeld.de/ download/2934907/2934909/ ISSN_Gold-OA_Matching_3.o_ documentation.pdf
COAlition $s$ (2020). COAlition $s$ invites qualified providers to develop a Plan $S$ Journal Checker tool. 7.2.2020. https://www.coalition-s.org/journal-checker-tool-tender/.

Julkaisufoorumi (2019). Suomalaiset tiedelehdet DOAJ-rekisteriin. I3.I2.2019, päivitetty 5.3.2020. https://bit.ly/2sWwRhU.

Tutkimusjulkaisujen avoimen saatavuuden linjaus. Vastuullisen tieteen julkaisusarja I: 20I9. Tiedonjulkistamisen neuvottelukunta ja Tieteellisten seurain valtuuskunta, Helsinki. Dor: https://doi. org/I 0.23847 /isbn.9789525995206

\section{Tietoa kirjoittajasta}

Eeva Savolainen

Tieteellisten seurain valtuuskunta eeva.savolainen@tsv.fi 